\title{
Growth Performance and Nutrient Utilization of the Cichlid, Commonly Called 'Wesafu' Reared In Hapa
}

\author{
Megbowon Iwalewa \\ Department of Aquaculture, Nigerian Institute for Oceanography and Marine Research, Victoria Island, Lagos
}

\begin{abstract}
The ecotype cichlid, 'wesafu', as it is commonly called, grows to a massive size of $1.5 \mathrm{~kg}$ and $414 \mathrm{~mm}$ total length in the wild, which makes it a fish of great aquacultural importance in Lagos, Nigeria. The study was conducted to evaluate its growth performance and nutrient utilization when reared in hapa. 50 Fingerlings with average weight of $7.73 \mathrm{~g}$ were allocated into $1 \mathrm{~m}^{3} \mathrm{~m}$ hapa installed in a $0.025 \mathrm{ha}$ pond and replicated. Four experimental diets $\left(T_{1}, T_{2}, T_{3}\right.$ and $\left.T_{4}\right)$ were formulated with crude protein levels of $15 \%, 25 \%, 35 \%$ and $45 \%$ respectively, using a locally fabricated pelletizing machine, with particle sizes of 1.5-2.0 mm. Fish were fed 3\% of their body weight twice daily while samplings were carried out forthnightly. The results showed that fish fed $T_{4}($ Crude protein of $45 \%)$ recorded the highest growth performance and nutrient utilization. This was followed by $T_{3}, T_{2}$ while $T_{1}$ had the least of these indices. No significant difference $(P<0.05)$ was observed in fish survival and the range was 78.7-87.8. It showed that final weight gain was significantly higher while FCR was significantly lower in $T_{4}$ and $T_{3}$ when compared to $T_{1}$ and $T_{2}$. The Food Conversion Ratio was least in $T_{4}$ and $T_{3}$ indicating better nutrient utilization. Similarly, protein efficiency was enhanced when the crude protein was increased. There was however no significant $(P<0.05)$ variation in the growth performance and nutrient utilization between $T_{3}(35 \%)$ and $T_{4}(45 \%)$ crude protein levels. It can therefore be inferred that the optimum protein requirement for the studied fish ('wesafu') is $35 \%$ crude protein. The extra cost incurred on the addition protein $\left(T_{3}\right.$ to $\left.T_{4}\right)$ did not produce any appreciable increase in growth. Feeding above this level will lead to increased cost with little or no proportionate benefit.
\end{abstract}

Key Words: Growth, Performance, Nutrient utilization, cichlid, 'wesafu'

\section{Introduction}

Aquaculture is growing rapidly to provide food fish for the world's growing population and presently provides approximately $40 \%$ of food fish consumed by man (FAO, 2006). It is presently the fastest growing sector of food production globally (FAO, 2004). Many capture fisheries are presently fished at or above maximum sustainable yields (MSY), and there is, therefore a tremendous global decline because of over exploitation and habitat degradation (FAO, 2004). The total production from aquaculture in 2009 was 55.1 million tons/year and freshwater aquaculture accounted for 35.0 million tons/year of this production $(63.5 \%)$. The present global population of 6.91 billion consumes about 118 million tons/year of fisheries products. It is predicted that a population of 9.15 billion would need about 156 million tons/yr (an additional 34 million tons/year) by 2050. Because fisheries production from the wild is on decline, aquaculture is expected to supply the entire future increase in demand of fisheries products. In order meet the increase in fish demand, it is expected that aquaculture production should be increased by 50 million metric tons by 2050 .

Tilapias represent an important freshwater species of fish for aquaculture in different regions of the world. They are characterized by fast growth, adaptability to a wide range of environmental variables, disease resistant and high flesh quality. They have the ability to reproduce under varying culture conditions and readily convert food low in plant protein to high quality flesh (El-Sayed, 2006). In Nigeria there exist an ecotype cichlid, called 'wesafu' in Epe lagoon, Lagos state where it is highly priced and grows to a size of over 1,500g in the wild (Bombatta et al,2005, 2007, 2008, Fashina-Bombata and Megbowon, 2012). This makes it a fish of great aquaculture potential in Lagos where it is abundantly caught and farmed. The large size of 'wesafu' coupled with deep body equally makes it a fish of great potential for filleting (Megbowon, 2010 and Megbowon et al, 2009). In Nigeria a kilogram of the fish sells for over 6.5 US Dollar equivalents (Megbowon and FashinaBombata, 2010). Many studies have been carried out on 'wesafu'. These include genetic characterization, amino acid profile, food and feeding habit and morphometrics. Although 'wesafu' is assumed to be a fish of great aquaculture potential, no work has been reported on the protein requirement when reared in hapa. The present study therefore seeks to find the optimum protein requirement for the culture of the ecotype cichlid, 'wesafu' in hapas. 


\section{Methodlogy}

This study was conducted at a fish farm in Lagos, Nigeria, where hapas were installed in a $0.025 \mathrm{ha}$ pond. The experiment lasted 12 weeks.

\section{Rearing And Experimental Fish}

The experimental rearing facility consisted of series of hapas $(1 \mathrm{~m} \times 1 \mathrm{~m} \mathrm{X} 1 \mathrm{~m})$. The depth of water in the hapas was maintained at $0.75 \mathrm{~m}$ by fixing the hapas to a rectangular framework of PVC pressure pipes, each carrying four hapas. Each rectangular framework carried 4 nos of 30 litre plastic keg at opposite ends to ensure floatation. Each rectangular framework was placed in the 0.025 ha pond using $300 \mathrm{~g}$ weight sinker at the four edges of the lower ends of the hapa. The experimental fish were bred on the farm and they were apparently healthy. The average weights of the fish were $7.73 \mathrm{~g} / \mathrm{fish}$.

\section{Feed And Feed Ingredients}

The main feed ingredients used in the present study were herring fish meal, soya bean meal, wheat offal, yellow maize, vitamins and minerals mixture. All the feed ingredients were purchased from the local market in Lagos. The chemical compositions of ingredients used in the experimental diets are presented in table (1).

Table 1: The chemical composition (\%) of the ingredients used in formulating the experimental diets.

\begin{tabular}{|c|c|c|c|c|c|c|c|c|}
\hline INGREDIENTS & Moist. & $\mathbf{C P}$ & EE & $\mathbf{C F}$ & Ash & NFE & \multicolumn{2}{|c|}{ GE (Kcal/kg } \\
\hline Yellow corn & & 11.2 & 8.46 & 3.82 & 2.62 & 1.34 & 83.1 & 4185 \\
\hline Fish meal & & 8.9 & 71.97 & 8.39 & 0.71 & 10.50 & 8.38 & 5128 \\
\hline Soyabean meal & & 11.96 & 44.75 & 1.20 & 7.31 & 5.38 & 41.30 & 4253 \\
\hline Wheat offal & & 10.96 & 14.97 & 3.95 & 12.10 & 6.30 & 62.69 & 4782 \\
\hline
\end{tabular}

Four experimental diets $\left(T_{1}, T_{2}, T_{3}\right.$ and $\left.T_{4}\right)$ were formulated with crude protein levels of $15 \%, 25 \%$, $35 \%$ and $45 \%$ respectively, using a locally fabricated pelletizing machine, with particle sizes of $1.5-2.0 \mathrm{~mm}$. The experiment was replicated. Fish were fed 3\% of their body weight twice daily. Samplings were carried out biweekly.

Table 2: Formulation and chemical composition of Experimental diets

\begin{tabular}{|c|c|c|c|c|}
\hline INGREDIENTS & $\mathrm{T}_{1}(15 \%)$ & $\mathrm{T}_{2}(25 \%)$ & $\mathbf{T}_{3}(35 \%)$ & $\mathrm{T}_{4}(\mathbf{4 5 \%})$ \\
\hline Yellow corn & 38.30 & 33.76 & 29.26 & 24.81 \\
\hline Fish meal (71.97\%) & 21.80 & 19.51 & 19.44 & 18.90 \\
\hline Soyabean Meal $\quad 44.75$ & 5\%) 21.79 & 22.13 & 21.10 & 21.40 \\
\hline Wheat offal & 14.61 & 21.10 & 26.70 & 31.39 \\
\hline Soybean oil & 2.00 & 2.00 & 2.00 & 2.00 \\
\hline Vitamin and mineral mi & hix 1.50 & 1.50 & 1.50 & 1.50 \\
\hline Total & 100 & 100 & 100 & 100 \\
\hline
\end{tabular}

Each kilogram of vitamin/mineral mixture contained; Vitamin A 4.8 I.U, Vitamin $\mathrm{D}_{3}$ 0.8I.U, Vitamin E, 4.8g, Vitamin $\mathrm{K}, 0.8 \mathrm{~g}$, vitamin $\mathrm{B}_{1}, 0.3 \mathrm{~g}$, vitamin $\mathrm{B}_{2}, 1.5 \mathrm{~g}$, vitamin $\mathrm{B}_{6} 0.5 \mathrm{~g}$, vitamin $\mathrm{B}_{12}, 3.5 \mathrm{~g}$, Pantothetic acid, 4.0g, Nicotinic acid, 7.5g, Folic acid, 350mg, Biotin, 20g, Sodium Chloride 200g and Iodine, 4g.

\section{Growth Performance}

Mean weight gain, Specific growth rate (SGR), food conversion rate (FCR), and survival were calculated as follows:

1. Weight gain $=\mathrm{W}_{1}-\mathrm{W}_{0}$

2. Specific growth rate $=\left(\ln \mathrm{W}_{1-} \ln \mathrm{W}_{0} / \mathrm{T}\right) \times 100$

3. Average daily Growth rate $=$ Weight gain $/ \mathrm{T}$ )

4. Food conversion rate $=$ Feed intake $(\mathrm{g}) /$ Weight gain $(\mathrm{g})$

5. Protein Efficiency Ratio (PER) = Weight gain/protein intake

6. Survival $(\%)=$ Number of experimental fish at the end of experiment

Where:

Number of experimental fish at the beginning of experiment

$\mathrm{W}_{0}=$ Mean initial weight $(\mathrm{g})$

$\mathrm{W}_{1}=$ Mean final weight $(\mathrm{g})$

$\mathrm{T}=$ Experimental period (days) 


\section{Stastical Analysis}

Growth and survival rates were compared using one-way analysis of variance (ANOVA) and Fisher's LSD to determine significant differences between means. Because mean initial weights differed significantly among the groups studied, the specific growth rate (SGR) of the fish were compared using Analysis of covariance with the initial weight serving as covariate.

\section{Results}

Table 1 showed the mean initial weight, mean final weight, weight gain, specific growth rate (SGR), food conversion rate (FCR) and survival rate (SR) for 'wesafu' fed varying crude protein levels and reared in hapas for 12 weeks. The fish fed $\mathrm{T}_{4}$ (Crude protein of $45 \%$ ) recorded the highest growth performance and nutrient utilization. This was followed by $T_{3}, T_{2}$ while $T_{1}$ had the least of these indices. No significant difference (P.0.05) was observed in fish survival and the range was 78.7- 87.8.

Furthermore, final weight gain was significantly highest while FCR was significantly lower in $\mathrm{T}_{4}$ and $T_{3}$ when compared to $T_{1}$ and $T_{2}$. The Food Conversion Ratio of were least in $T_{4}$ and $T_{3}$ indicating better nutrient utilization. Similarly, protein efficiency was enhanced when the crude protein was increased (Table 1).

The growth pattern revealed substantial increases in weight gain in every bi-weekly reading (Fig. 1) with $\mathrm{T}_{4}$ showing better growth still.

Table 1. Mean Growth and survival rates of 'wesafu' fed varying levels of crude protein and reared in hapas

\begin{tabular}{ccccc}
\hline PRODUCTIVE INDEX & $\mathrm{T}_{1}(15 \%)$ & $\mathrm{T}_{2}(25 \%)$ & $\mathrm{T}_{3}(35 \%)$ & $\mathrm{T}_{4}(45 \%)$ \\
\hline Initial Weight $(\mathrm{g}) \pm$ S.E. & $7.73 \pm 0.97^{\mathrm{a}}$ & $7.73 \pm 0.95^{\mathrm{a}}$ & $7.73 \pm 0.99^{\mathrm{b}}$ & $7.73 \pm 0.93^{\mathrm{b}}$ \\
Final Mean weight $(\mathrm{g}) \pm$ & $31.8 \pm 1.87^{\mathrm{a}}$ & $38.91 \pm 2.75^{\mathrm{b}}$ & $40.97 \pm 3.8 .^{\mathrm{b}}$ & $42.04 \pm 2.84^{\mathrm{b}}$ \\
S.E. & $24.07 \pm 2.0^{\mathrm{a}}$ & $31.18 \pm 2.2^{\mathrm{b}}$ & $33.84 \pm 2.5^{\mathrm{b}}$ & $34.31 \pm 2.6^{\mathrm{a}}$ \\
Weight Gain $(\mathrm{g}) \pm$ S.E. & $2.61 \pm 0.05^{\mathrm{b}}$ & $2.65 \pm 0.03^{\mathrm{a}}$ & $2.69 \pm 0.06^{\mathrm{a}}$ & $2.71 \pm 0.05^{\mathrm{a}}$ \\
PER & $4.82 \pm 0.17^{\mathrm{a}}$ & $4.85 \pm 0.27^{\mathrm{a}}$ & $4.86 \pm 0.17^{\mathrm{a}}$ & $4.89 \pm 0.24^{\mathrm{a}}$ \\
SGR (\% /day) \pm S.E. & $2.65 \pm 0.21^{\mathrm{b}}$ & $2.46 \pm 0.19^{\mathrm{b}}$ & $2.39 \pm 0.27 \mathrm{a}$ & $2.37 \pm 0.17 \mathrm{a}$ \\
FCR \pm S.E & $87.8 \pm 2.32^{\mathrm{a}}$ & $86.4 \pm 2.91^{\mathrm{a}}$ & $82.4 \pm 2.73^{\mathrm{a}}$ & $78.7 \pm 3.36^{\mathrm{a}}$ \\
\hline Survival Rate $(\%) \pm$ S.E) &
\end{tabular}

Means $(\mathrm{n}=3)$ in each row with same superscript were not significantly different $(\mathrm{P}>0.05)$

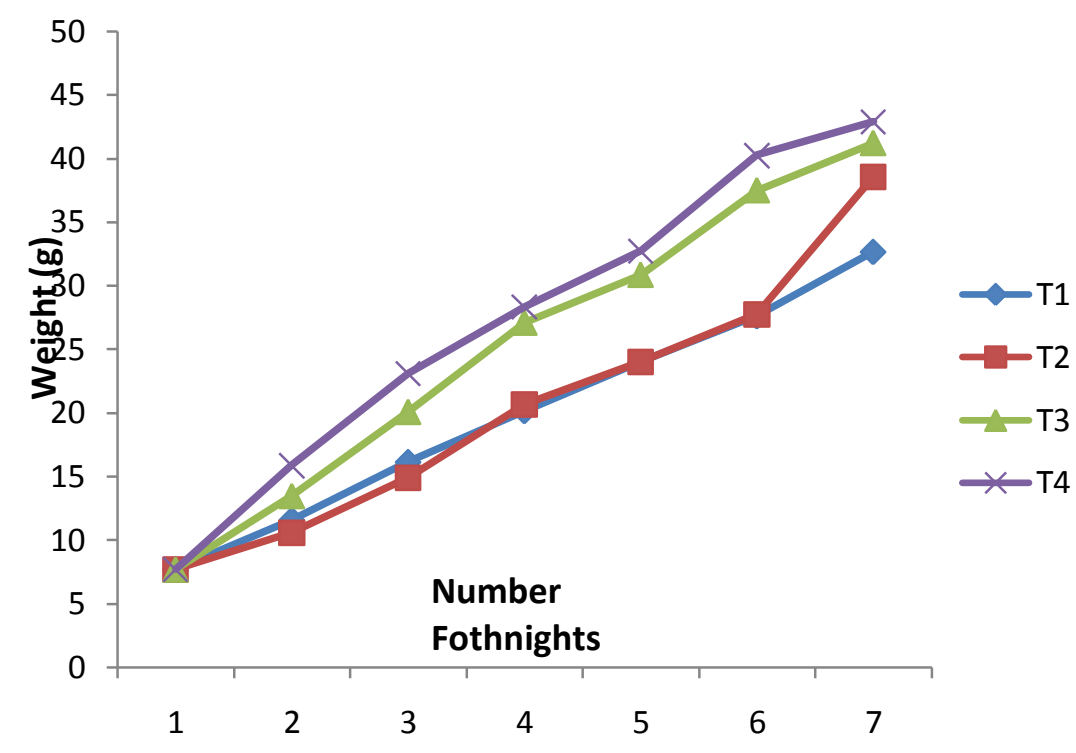

Fig 1: Growth pattern of the ecotype cichlid, 'wesafu' reared in hapas

\section{Discussion}

Prepared diet provides essential nutrients that are required for normal growth and physiological functions of cultured fish. Protein requirements of cichlid fishes, particularly tilapia have been extensively studied using dose-response procedures (El-Sayed, 2006). However, the utility of the results of many studies is questionable, because they were indoor, short-term studies and the outcomes may not be directly applicable in commercial rearing facilities. 
The results of the present study (involving hapa installed in pond) indicated that the highest performance and nutrient utilization was obtained when fish were fed a diet $\mathrm{T}_{4}$, containing $45 \%$ crude protein. All the growth parameters (weight gain, SGR, PER and FCR) indicated better performance. There was however no significant $(\mathrm{P}<0.05)$ variation in the growth performance and nutrient utilization between $\mathrm{T}_{3}(35 \%)$ and $\mathrm{T}_{4}$ $(45 \%)$ crude protein levels. It can therefore be inferred that the optimum protein requirement for the studied fish ('wesafu') is $35 \%$ crude protein. The extra cost incurred on the addition protein did not bring any appreciable increase in growth. Feeding above this level will lead to increase cost with little or no proportionate benefit.

Several authors have reported that protein is the most expensive dietary source in intensive aquaculture. It represents about 50\% of total feed costs (El-Sayed, 2006). Other workers such as Abdelghany (2000) reported 35\% crude protein as the optimum requirement for fingerlings of Oreochromis niloticus. Jauncey and Rose (1982) on the other hand reported 30-35\% for O.mossamicus while El-Sayed (1987) reported 35\% for Tilapia zilli fingerlings. Generally, for tilapia juveniles, the protein requirement ranges from 30 to $40 \%$, while adult tilapias require 20-30\% dietary protein for optimum performance (El-Sayed, 2006). Protein requirements of tilapia depend, among other things, on fish size or age, protein source and the energy content of the diets. Generally speaking, protein requirement decreases with increasing fish size.

\section{Acknowledgement}

I wish to acknowledge the Nigerian Institute for Oceanography for providing fund for the study. I equally wish to appreciate Professor Fashina-Bombata H.A who willingly offered his fish farm to be used for the study.

\section{References}

[1]. Abdelghany, A.E. (2000a) Optimum dietary protein requirements for Oreochromis niloticus L. fry using formulated semi-purified diets. In: Fitzsimmons, K. and Filho, J.C. (eds) Tilapia Culture in the 21st Century, Proceedings from the Fifth International Symposium on Tilapia Aquaculture, Rio de Janeiro, Brazil. American Tilapia Association, Charles Town, West Virginia, and ICLARM, Penang, Malaysia, pp. 101-108.

[2]. El-Sayed, A.-F.M. (1987) Protein and energy requirements of Tilapia zillii. PhD thesis, Michigan State University, East Lansing, Michigan.

[3]. FAO (Food and Agriculture Organization of the United Nations) (2004) Fishstat Plus. FAO, Rome

[4]. Fashina-Bombata H.A and I. Megbowon (2012). Proximate composition and breeding description of an unidentified Cichlid of Epe Lagoon, Lagos, Southwest, Nigeria commonly called 'Wesafu'. International Journal of Nutrition and Metabolism Vol. 4(4), pp. 57-63,

[5]. Fashina-Bombata, H.A., Ajepe, R.G. and Hammed, A.M. (2008): Age and Growth of an

[6]. Ecotype Cichlid 'Wesafu' in Epe Lagoon, Lagos, Nigeria. Global Journal of Agricultural Sciences Vol. 7(1): 105109.

[7]. Fashina-Bombata, H.A., Hammed, A.M. and Ajepe, R.G. (2006): Food and from Epe lagoon, Lagos, Nigeria. World Aquaculture 37(1):63-66.

[8]. Fashina-Bombata, H.A., Ajepe, R.G., Hammed, A.M. and Jimoh, A.A. (2005): Characterization of an Ecotype Cichlid commonly referred to as "Wesafu" endemic to Epe-Lagoon, Nigeria. World Aquaculture $36 \quad$ (4):20-22.

[9]. Jauncey, K. and Ross, B. (1982) A Guide to Tilapia Feeds and Feeding. University of Stirling, Stirling, Scotland, 111 pp.

[10]. Megbowon I, Bombata-Fashina, H.A, Mojekwu, T.O and Okunade O. (2009). Genetic Improvement of Tilapia: Challenges and Prospects in Nigeria. Nigeria journal of Fisheries. Vol. 6, (1\&2), pp21-30.

[11]. Megbowon I. and Fashina-Bombat, H.A. (2010). Tilapia: Fish for the Millennium. Fish Network. Fisheries Society of Nigeria's quarterly publication (Supported by World bank/ NSME Nigeria), Vol. 111, pp36-40.

[12]. Megbowon I (2011). Tilapia production in Nigeria. Fish Network, FISON quarterly publication (Supported by W orld bank/ NSME), ppn18-22. 